\title{
PENERAPAN MODEL PEMBELAJARAN BERBALIK (RECIPROCAL TEACHING) DITINJAU DARI AKTIVITAS DAN HASIL BELAJAR SISWA
}

\author{
Ira Vahlia ${ }^{1}$, Satrio Wicaksono Sudarman ${ }^{2}$ \\ Pendidikan Matematika FKIP Universitas Muhammadiyah Metro \\ E-mail: iravahlia768@ yahoo.co.id ${ }^{1)}$ \\ rio_sudarman@yahoo.com ${ }^{2)}$
}

\begin{abstract}
The aim of the research was to determine the effect of learning models on mathematics achievement viewed from the student activity. Many factors influence the results of student learning, including learning system used in presenting the subject matter inappropriate, as well as the lack of students understand the concepts being taught. Based on the results of the pre-survey, retrieved the data value of the Mid Semester Even-Numbered Years Lessons 2014/2015 that of the 23 students there are 13 students who are learning or mastery of 56,52\%. It takes the efforts of teachers to choose the model of learning material appropriate to each lesson. For the average activity of students obtained an increase in the activity of learning from $52,42 \%$ on cycle I became 64,2\%5 in cycle II. As for the student learning outcomes there is also increased, the average results of the learn cycle I is 63,54, while on cycle II increased to 70,65 and success of the student learning at the end of the cycle reaches 81,09. It was concluded that the reciprocal teaching model, can improve the learning results of activity and grade VIII SMP Negeri 4 Metro.
\end{abstract}

Keywords : activity, study result, reciprocal teaching

PENDAHULUAN

Matematika merupakan ilmu universal yang mendasari perkembangan teknologi modern. Perkembangan pesat di bidang teknologi informasi dan komunikasi dewasa ini dilandasi oleh perkembangan matematika di bidang teori bilangan, aljabar, analisis, teori peluang, dan matematika diskrit. Untuk menguasai dan menciptakan teknologi di masa depan maka diperlukan

penguasaan matematika yang kuat sejak dini. Mata pelajaran matematika perlu disampaikan kepada semua peserta didik mulai dari sekolah dasar untuk membekali peserta didik dengan kemampuan berpikir logis, analitis, sistematis, kritis dan kreatif, serta kemampuan bekerjasama. Kompetensi tersebut diperlukan agar peserta didik dapat memiliki kemampuan memperoleh, mengelola dan memanfaatkan informasi untuk 
bertahan hidup pada keadaan yang selalu berubah, tidak pasti dan kompetitif.

Upaya yang dilakukan SMP Negeri 4 Metro dalam meningkatkan mutu pendidikan di sekolah cukup baik, seperti memilih guru yang memiliki kemampuan sesuai dengan mata pelajaran, menggunakan strategi pembelajaran yang baik (ekspositori, cooperative learning dan inquiry), memperbaiki dan melengkapi sarana prasarana yang mendukung seperti LCD dan $c c t v$ disetiap kelas, ruang multimedia dan perpustakaan digital sehingga siswa dapat mengakses berbagai informasi, fasilitas hotspot disekolah, penambahan jam pelajaran setiap minggunya untuk mata pelajaran matematika, selain itu pemberian les di sekolah setelah pulang sekolah, serta mengikutsertakan guru-guru dalam penataran. Tetapi usaha tersebut belum dapat memberikan hasil yang optimal. Berdasarkan hasil pra survey, hasil belajar matematika yang diperoleh siswa SMP Negeri 4 Metro khususnya

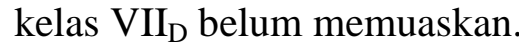

Hal ini terlihat dari jumlah siswa yang memperoleh nilai dibawah Kriteria Ketuntasan Minimal (KKM) pada pelajaran matematika yang ditetapkan sebesar 75 belum mencapai target yang diinginkan sekolah yaitu 100 $\%$. Sebagian besar siswa kelas $\mathrm{VII}_{\mathrm{D}}$ mengalami kesulitan dalam menyelesaikan permasalahan matematika. Hal ini dapat dibuktikan dengan rendahnya hasil belajar siswa kelas $\mathrm{VII}_{\mathrm{D}}$ mid semester ganjil di SMP Negeri 4 Metro. Sehingga perlu adanya upaya peningkatan terhadap aktivitas belajar siswa karena diduga hal tersebut termasuk faktor yang mempengaruhi hasil belajar siswa. Menurut Rohani (2005: 6), menyatakan bahwa belajar yang berhasil mesti melakukan berbagai macam aktivitas, baik aktivitas fisik maupun psikis.

Diketahui bahwa aktivitas siswa seperti mengerjakan latihan dikelas dan berdiskusi dalam kelompok sudah cukup baik, namun aktivitas siswa seperti bertanya dan mengeluarkan pendapat sangat rendah. Untuk itu dengan menggunakan model pembelajaran berbalik (reciprocal teaching) yang didalamnya terdapat aktivitas siswa menjelaskan materi kepada siswa lainnya, sehingga siswa menjadi termotivasi untuk mengusai terlebih dahulu materi yang belum dijelaskan pada pertemuan yang akan datang dan apabila ada materi yang belum dimengerti dapat bertanya dan mengeluarkan pendapat pada saat proses pembelajaran berlangsung.

Dari hasil prasurvey, kelas $\mathrm{VII}_{\mathrm{D}}$ merupakan kelas unggulan di SMPN 4 Metro. Dengan adanya kemampuan yang dimiliki siswa serta aktivitas yang merupakan modal utama sehingga dapat 
digunakan model pembelajaran berbalik (reciprocal teaching) dalam proses pembelajaran, yang diduga dapat membuat siswa lebih aktif dan prestasi belajar matematika akan meningkat. Aktivitas siswa dapat meningkat dengan mencari berbagai sumber yaitu dari internet dan perpustakaan digital sehingga dapat berbagi informasi kepada siswa lainnya.

Menurut Rachmayani (2014: 22), reciprocal teaching dapat meningkatkan kemandirian siswa yang disalamnya terdapat berbagai macam aktivitas siswa sehingga dapat meningkatkan hasil belajar siswa. Didalam model pembelajaran berbalik (Reciprocal Teaching) dapat mengeksplorasi kemampuan siswa dan menekankan adanya aktivitas serta interaksi diantara peserta didik untuk saling memotivasi dan membantu dalam menguasai materi pelajaran guna mencapai prestasi yang maksimal. Selain itu dapat memungkinkan terjadinya suatu sistem pembelajaran tutor sebaya yang dapat membantu peserta didik yang tidak berani dalam memberi tanggapan dan pendapat nantinya dapat berinteraksi dengan teman sekelasnya. Dalam Suyatno (2009: 6), Panen menguraikan bahwa melalui pembelajaran berbalik ini siswa dapat mengembangkan kemauan belajar mandiri, memiliki kemampuan untuk mengembangkan pengetahuannya sendiri, melatih siswa agar dapat mempresentasikan idenya, dan guru berperan sebagai fasilitator, mediator, dan manager dari proses pembelajaran". Siswa menjadi lebih paham terhadap materi yang dipelajari karena termotivasi untuk menjelaskan kepada teman lainnya, sehingga aktivitas belajarnya semakin meningkat.

\section{METODE PENELITIAN}

Subyek penelitian ini adalah siswa kelas $\mathrm{VII}_{\mathrm{D}}$ semester ganjil SMPN 4 Metro yang berjumlah 23 siswa, terdiri dari 11 siswa putra dan 12 siswa putri. Menurut Arikunto (2006: 16), model penelitian tindakan kelas dalam satu siklus terdiri dari empat langkah, yaitu : 1) Perencanaan (Planning), 2) Pelaksanaan (Acting), 3) Pengamatan (Observing), dan 4) Refleksi (Reflecying).

Prosedur Penelitian tindakan kelas ini terdiri dari dua siklus, tiap siklus akan diadakan perubahan pelaksanaan sesuai dengan faktor yang ingin diteliti. Untuk melihat aktivitas dan hasil belajar siswa, maka diberikan tes diagnostik yang berfungsi sebagai evaluasi awal. Sedangkan observasi awal dilakukan untuk mengetahui tindakan yang diberikan dalam rangka meningkatkan aktivitas dan hasil belajar siswa, terutama dalam pembelajaran matematika. 


\section{HASIL PENELITIAN DAN PEMBAHASAN}

Data Hasil Belajar Siswa Siklus 1

Hasil analisis data hasil belajar siswa diperoleh rata-rata nilai siswa pada pre tes siklus I adalah 47,61 dengan presentase ketuntasan 21,74\% Sedangkan rata-rata hasil belajar siswa pada pos tes siklus I adalah 70,65 dengan presentase ketuntasan $60,87 \%$. Berdasarkan data tersebut menunjukkan bahwa ketuntasan belajar pada pre tes siklus 1 telah terjadi peningkatan dibandingkan dengan pos tes siklus 1 yaitu $39,13 \%$ dengan nilai terendah 20 dan nilai tertinggi adalah 80 pada saat Pre tes, kemudian menjadi $60,87 \%$ dengan nilai terendah adalah 55 dan nilai tertinggi adalah 85 pada pos tes. Namun persentase siswa yang tuntas belum mencapai target yang diinginkan yaitu $\geq 80 \%$. Untuk skor rata-rata hasil belajar pada pre tes siklus I juga terjadi peningkatan dibandingkan dengan pos tes siklus 1 , yaitu 47,61 pada saat pre tes menjadi 70,65 pada pos tes siklus I.

\section{Refleksi Siklus}

Setelah pelaksanaan siklus I selesai, kemudian diadakan refleksi. Refleksi ini dimaksudkan untuk mengkaji secara menyeluruh tindakan yang telah dilakukan. Berdasarkan data yang telah terkumpul pada siklus I, baik pre tes, pos tes, aktivitas siswa, dan aktivitas guru selama kegiatan belajar mengajar. Setelah itu dilakukan evaluasi guna menyempurnakan tindakan berikutnya. Pada akhir siklus I diperoleh data bahwa aktivitas siswa meningkat dari setiap pertemuan, tetapi belum semua aktivitas memenuhi kriteria keberhasilan yang ditetapkan. Pada akhir siklus I diperoleh ratarata hasil belajar siswa 70,65 dengan presentase ketuntasan $60,87 \%$.

Data Hasil Belajar Siswa Siklus 2

Hasil analisis data hasil belajar siswa diperoleh rata-rata nilai siswa pada pre tes siklus II adalah 30,22 dengan presentase ketuntasan 13,04\% Sedangkan rata-rata hasil belajar siswa pada pos tes siklus II adalah 81,09 dengan presentase ketuntasan $82,61 \%$. Persentase siswa yang tuntas pada siklus II sudah mencapai target yang diinginkan yaitu $\geq 80 \%$. Untuk skor rata-rata hasil belajar pada pre tes siklus II juga terjadi peningkatan dibandingkan dengan Pos tes siklus II, yaitu 30,22 pada saat Pre tes menjadi 81,09 pada pos tes siklus II.

\section{a. Aktivitas Belajar Siswa}

Hasil analisis data pada lembar observasi aktivitas belajar 
siswa diketahui bahwa persentase siswa yang aktif $\geq 60$ sudah memenuhi kriteria keberhasilan yang dikehendaki. Persentase aktivitas belajar siswa siklus I dan siklus II dapat dilihat pada Tabel 1

Tabel 1. Perbandingan Aktivitas Belajar pada Siklus I dan Siklus II

\begin{tabular}{|c|l|c|c|c|}
\hline No & \multicolumn{1}{|c|}{ Jenis Aktivitas } & Siklus I & Siklus II & Peningkatan \\
\hline 1. & Menjelaskan materi & $23,19 \%$ & $31,88 \%$ & $8,69 \%$ \\
\hline 2. & Memperhatikan penjelasan & $84,06 \%$ & $94,20 \%$ & $10,14 \%$ \\
\hline 3. & Mengerjakan latihan dikelas & $82,61 \%$ & $97,10 \%$ & $14,49 \%$ \\
\hline 4. & Berdiskusi & $81,16 \%$ & $92,75 \%$ & $11,59 \%$ \\
\hline 5. & Bertanya & $23,19 \%$ & $36,23 \%$ & $13,04 \%$ \\
\hline 6. & Mengeluarkan pendapat & $20,29 \%$ & $33,33 \%$ & $13,04 \%$ \\
\hline \multicolumn{2}{r}{ Jumlah } & $314,49 \%$ & $385,51 \%$ & $71,02 \%$ \\
\hline \multicolumn{2}{|c|}{ Rata-rata aktivitas siswa } & $52,42 \%$ & $64,25 \%$ & $11,83 \%$ \\
\hline
\end{tabular}

Berdasarkan hasil penelitian yang telah diuraikan diatas, maka diperoleh gambaran umum tentang bagaimana penggunaan model pembelajaran berbalik (Reciprocal Teaching) dapat meningkatkan aktivitas dan hasil belajar siswa pada pokok bahasan persamaan dan pertidaksamaan linear dengan satu variabel (Equation and Inequality With One Variable)

\section{b. Aktivitas Guru Pada Saat Pembelajaran}

Hasil pengamatan terhadap aktivitas guru diperoleh data bahwa guru telah melaksanakan semua aspek yang diamati, namun dalam pelaksanaannya masih belum maksimal. Pada siklus I pertemuan pertama dari 10 aspek yang diamati didapat 6 aspek yang sudah dilaksanakan dengan baik. Pertemuan kedua didapat 8 aspek yang sudah dilaksanakan dengan baik sedangkan pada pertemuan ketiga didapat 7 aspek. Pada siklus II pertemuan pertama dari 10 aspek yang diamati didapat 8 aspek yang sudah dilaksanakan dengan baik. Pertemuan kedua didapat 9 aspek yang sudah dilaksanakan dengan baik sedangkan pada pertemuan ketiga didapat 10 aspek.

Pada awal pelaksanaan pembelajaran dengan model pembelajaran berbalik (Reciprocal Teaching), siswa belum terbiasa dalam menjelaskan materi kedepan kelas dengan menggunakan model pembelajaran berbalik (Reciprocal Teaching). tetapi seiring berjalannya waktu, pengelolaan pembelajaran semakin baik dan mengalami peningkatan. Aktivitas guru setiap siklus mengalami peningkatan. Guru mampu memperbaiki kekurangan-kekurangan pada saat pembelajaran di setiap pertemuan 
dengan selalu meminta masukan dari observer maupun dari refleksi yang dilaksanakan pada akhir siklus.

\section{c. Hasil Belajar Siswa}

Dari hasil penelitian

matematika siswa dalam pembelajaran dengan menggunakan model pembelajaran berbalik (Reciprocal Teaching) pada siklus I dan siklus II dapat dilihat pada Tabel 2. diperoleh data skor hasil belajar

Tabel 2. Perbandingan Hasil Belajar pada Siklus I dan Siklus II

\begin{tabular}{|c|c|c|c|c|c|c|}
\hline \multirow{2}{*}{ No } & \multirow{2}{*}{ Kategori } & \multirow{2}{*}{$\mathrm{N}$} & \multicolumn{2}{|c|}{ Banyak Siswa } & \multicolumn{2}{c|}{ Persentase } \\
\cline { 4 - 7 } & & Siklus I & Siklus II & Siklus I & Siklus II \\
\hline 1 & Tuntas & $\geq 75$ & 14 & 19 & $60,87 \%$ & $82,61 \%$ \\
\hline 2 & Tidak Tuntas & $<75$ & 9 & 4 & $39,13 \%$ & $17,39 \%$ \\
\hline $\begin{array}{c}\text { Nilai rata-rata belajar } \\
\text { siswa }\end{array}$ & \multicolumn{5}{|c|}{70,65} & 81,09 \\
\hline
\end{tabular}

Berdasarkan tabel di atas nilai rata-rata belajar siswa meningkat dari setiap siklusnya, di mana pada siklus I rata-rata hasil belajar siswa 70,65 sedangkan pada siklus II menjadi 81,09 sehingga terjadi peningkatan sebesar 10,44. Pada siklus I siswa yang mendapat nilai sesuai dengan KKM $\geq 75$ sebanyak 60,87\%, sedangkan pada siklus II meningkat menjadi $82,61 \%$. Dengan demikian ketuntasan belajar pada siklus II telah mencapai atau memenuhi indikator keberhasilan tindakan, yaitu siswa yang mendapat nilai $\geq 75$ minimal sebanyak $80 \%$ dari jumlah seluruh siswa.

Berdasarkan tabel di atas terlihat ada peningkatan hasil belajar siswa yang nilainya pada kategori tuntas dari 14 siswa menjadi 19 siswa atau meningkat $21,74 \%$ sehingga hasil belajar pada siklus II lebih baik dari pada siklus I meskipun maih ada 4 siswa yang tidak tuntas, tetapi secara umum hasil belajar pada siklus II sudah memenuhi indikator keberhasilan yang ditetapkan. Hal ini menunjukkan bahwa pembelajaran dengan menggunakan model pembelajaran berbalik (Reciprocal Teaching) terlihat meningkatkan rata-rata hasil belajar siswa karena siswa terlibat aktif dalam proses pembelajaran. Selain menambah pemahaman siswa tentang materi yang dipelajari, siswa juga meningkatkan rasa percaya diri dalam mengungkapkan pendapat dalam berdiskusi bersama-sama temannya. Dalam pembelajaran dengan menggunakan model pembelajaran berbalik (Reciprocal Teaching) siswa juga belajar menghargai pendapat dan hasil penjelasan temannya serta saling 
bertukar pikiran dalam
menyelesaikan tugas

diberikan oleh guru.

Peningkatan hasil belajar dari siklus I ke siklus II disebabkan karena dalam model pembelajaran berbalik (Reciprocal Teaching) ini siswa harus mampu memahami materi terlebih dahulu kemudian menjelaskan kepada teman lainnya dengan media powerpoint maupun bahasa serta cara yang lebih dimengerti oleh siswa, siswa merasa senang karena dalam pembelajaran siswa diberi kesempatan ikut aktif terlibat langsung dalam menemukan penyelesaian jawaban melalui contoh-contoh konkrit yang sederhana yang sifatnya telah dipahami oleh siswa. Siswa termotivasi untuk mengembangkan kemampuannya dalam berfikir setahap demi setahap. Siswa bisa menemukan sendiri, menjelaskan kepada siswa lain, mengeluarkan pendapat, maupun mengajukan pertanyaan dan mengemukakan ide-idenya kepada pihak lain, tentu menambah kemampuan nalar siswa, mempertinggi kemampuan siswa dalam memecahkan masalah. Oleh karena itu, keterlibatan siswa untuk belajar secara mandiri merupakan indikator keefektifan belajar. Siswa tidak hanya menerima saja materi yang diberikan oleh guru. Hasil pelajaran tidak hanya peningkatan pengetahuan, tetapi juga meningkatkan keterampilan

berpikir. Dengan demikian, implementasi pembelajaran berbalik (reciprocal teaching) diharapkan dapat meningkatkan hasil belajar dan melatih kemampuan siswa berbicara, khususnya dalam mata pelajaran matematika, maka sebagai guru perlu mengenal dan mempelajari model pembelajaran dan metode penyampaiannya. Pembelajaran berbalik (Reciprocal Teaching) dapat dan banyak digunakan sebagai alternatif dalam variasi pembelajaran matematika.

Dalam kegiatan belajar, aktivitas memegang peranan penting karena sangat menunjang hasil belajar. Hasil belajar akan tercapai dengan baik apabila aktivitas belajar itu tinggi. Penggunaan model pembelajaran berbalik (Reciprocal Teaching) dalam kegiatan pembelajaran menuntut siswa untuk menguasai materi, aktif berdiskusi, berbagi hasil jawaban dan mengerjakan latihan. Artinya model ini sangat memungkinkan untuk dapat meningkatkan aktivitas dan hasil belajar siswa mata pelajaran matematika dengan materi persamaan dan pertidaksamaan linear dengan satu variabel (Equation and Inequaliy With One Variable).

\section{KESIMPULAN DAN SARAN}

Berdasarkan hasil penelitian tindakan kelas dan pembahasan 
yang telah dikemukakan, maka dapat disimpulkan sebagai berikut: 1. Pembelajaran dengan menggunakan model pembelajaran berbalik dapat meningkatkan aktivitas belajar matematika siswa kelas VII Semester genap Tahun Pelajaran 2014/2015 SMP Negeri 4 Metro. Rata-rata aktivitas belajar siswa pada Pra PTK adalah 48,95\% dan diakhir siklus II diperoleh rata-rata aktivitas belajar adalah $64,25 \%$. Hal ini berarti aktivitas belajar siswa mengalami peningkatan sebesar $15,3 \%$

2. Pembelajaran dengan menggunakan model pembelajaran berbalik dapat meningkatkan hasil belajar matematika siswa kelas VII Semester ganjil SMP Negeri 4 Metro. Rata-rata peningkatan hasil belajar adalah dari 68,35 pada Pra PTK menjadi 81,09 pada siklus II. Untuk rata-rata ketuntasan belajar meningkat dari 56,52\% pada Pra PTK menjadi $82,61 \%$ pada siklus II.

3. Dalam proses pembelajaran dengan menggunakan model pembelajaran berbalik (Reciprocal Teaching) siswa lebih aktif berdiskusi dan menemukan berbagai cara dalam memecahkan masalah.

Berdasarkan hasil penelitian, terdapat beberapa hal yang peneliti sarankan yaitu:
1. Diharapkan agar siswa lebih memperhatikan pelajaran dan lebih aktif dalam mengikuti pembelajaran di kelas khususnya pada pelajaran matematika.

2. Dalam menggunakan pembelajaran model pembelajaran berbalik hendaknya lebih dipersiapkan semaksimal mungkin dalam tahap perencanaan dan pelaksanaan sehingga siswa dapat lebih mengeksplorasi kemampuannya.

\section{DAFTAR PUSTAKA}

Arikunto, Suharsimi. 2006. Penelitian Tindakan Kelas. Jakarta: PT Bumi Aksara.

Rachmayani, Dwi. 2014. Penerapan Pembelajaran Reciprocal Teaching Untuk Meningkatkan Kemampuan Komunikasi Matematis Dan Kemandirian Belajar Matematika Siswa. Unsika. ISSN: 2338-2996. Vol. 2, No. 1, PP 13-23.

Rohani, Ahmad. 2005. Pengelolaan Pengajaran. Jakarta: Rineka Cipta.

Suyatno. 2009. Menjelajah Pembelajaran Inovatif. Sidoarjo: Masmedia Buana Pustaka. 